\title{
Studi Beberapa Dosis Infus Daun Salam (Syzygium polyanthum [Wight.] Walp.) Sebagai Antidiare Pada Mencit (Mus musculus)
}

\author{
Sundari, Masruhen
}

Akademi Farmasi Putra Indonesia Malang

\begin{abstract}
ABSTRAK
Daun Syzygium pholyanthum Wight Walp masyarakat seringkali menyebutnya dengan sebutan daun salam biasanya digunakan masyarakat sebagai bumbu masak. salam merupakan salah satu tanaman obat yang memiliki banyak khasiat dalam mengobati berbagai penyakit,salah satunya sebagai obat diare.Penelitian ini bertujuan untuk mengetahui efek antidiare infuse daun salam dengan pengamatan jumlah feses, konsistensi feses, serta lama diare. Daun salam diperoleh dari Lembaga Ilmu Pengetahuan Indonesia ( LIPI ) UPT Balai Konservasi Tumbuhan Kebun Raya Purwodadi di Pasuruan.Hewan coba dibagi secara acak menjadi 8 kelompok terdiri dari kelompk yang tidak didiarekan, kelompok control positif,control negative serta kelompok diberikan infuse daun salam secara oral dengan berbeda dosis yaitu $15 \%, 20 \%, 25 \%, 30 \%$, dan 35\% b/v. Waktu pengamatan dilakukan setiap 1 jam selama 4 jam,evaluasi hasil dilakukan dengan menghitung jumlah feses, skor kosistensifeses serta lama diare mencit Analisis hasil penelitian yang digunakan adalah Analisis Varian ( ANAVA), dilanjutkan dengan uji Student Newman Keuls (SNK). Hasil analisis penelitian diperoleh data bahwa infuse daun salam dengan dosis $25 \%$ b/v, memberikan efek daya antidiare terbesar yaitu dengan rata rata jumlah feses 56\%, konsistensi feses sebesar 51,77\%, serta lama diare 36,66 menit. infuse daun salam dosis $15 \%$ rata rata jumlah $46,66 \%$, konsistensi feses $43,26 \%$, serta lama diare 46,66 menit. Salam.Dosis $20 \%$ rata rata jumlah feses $42,66 \%$, konsistensi feses 36,18, serta lama diare $51,67 \%$. Dosis $30 \%$ rata rata jumlah feses $32 \%$, konsistensi feses 33,33\%, serta lama diare 53,33\%.Dosis $35 \%$ rata rata jumlah feses 45,33\%, konsistensi feses 41,14\%, serta lama diare 51,67\%. Berdasarkan hasil penelitian dapat disimpulkan daun salam dapat mengurangi jumlah feses, lama diare serta meningkatkan konsisitensitensi feses rhadap mencit. semakin tinggi dosis infuse daun salam yang digunakan untuk antidiare belum tentu daya antidiare infuse daun salam semakin meningkat hal itu terbukti bahwa dosis $25 \%$ memiliki daya antidiare tertinggi dibanding dosis $15 \%, 20 \%, 30 \%$,dan $35 \%$, Dosis 25\% memiliki efek yang sama seperti efek yang dihasilkan oleh loperamid dosis 0,052 mg. Berdasarkan hasil penelitian disarankan, Masyarakat menggunakan daun salam sebagai obat antidiare dosis 25\%, Isolasi tannin yang terdapat dalam daun salam sehingga zat-zat lainya tidak ikut tersari sehingga memaksimalkan pengobatan diare, Dilakukan penelitian mengenai ED50. Senyawa kimia yang berkhasiat sebagai antidiare ini adalah tannin.
\end{abstract}

Kata Kunci: Daun Syzygium pholyanthum, diare, infus

\section{Latar Belakang}

Diare saat ini masih merupakan salah satu masalah kesehatan utama di indonesia, dengan insidensi 400 per 1.000 penduduk (Indonesia ,1988:108). Lebih dari separuh (60-70\%) penderita diare adalah anak berusia di bawah 5 tahun, penyakit diare ini terjadi terutama di daerah pedesaan. Penyakit ini merupakan suatu gejala klinis dan gangguan saluran pencernaan (usus) yang ditandai dengan bertambahnya frekuensi defekasi lebih dari biasanya (berulang-ulang), disertai adanya perubahan bentuk dan konsistensi dan feses menjadi lembek atau cair. Gejala diare atau mencret adalah tinja yang encer dengan frekuensi empat kali atau lebih dalam sehari yang kadang disertai muntah, badan lesu atau lemah, panas tidak bernafsu makan.

Faktor penyebab terjadinya diare antara lain infeksi oleh kuman, virus, atau parasit, alergi terhadap makanan atau obat 
tertentu, pemanis buatan, keadaan gizi, higiene, dan, sosial ekonomi. Masyarakat yang belum mendapat pelayanan kesehatan resmi sangat bergantung pada alam sekeliling untuk berupaya menanggulangi diare. Salah satu upaya untuk menanggulangi diare yakni melalui pengobatan tradisional. Pengobatan tradisional merupakan cara pengobatan dengan memanfaatkan bahan baku alam terutama tanaman obat yang telah diramu sedemikian rupa dan sudah diakui khasiatnya secara turun-temurun. Pemakaian obat tradisional tersebut telah lama dipraktikkan sehingga orang beranggapan bahwa penggunaan obat tradisional relatif lebih aman dibandingkan obat sintesis.

Salah satu tanaman obat yang dapat digunakan untuk pengobatan diare yaitu daun salam (Syzygium polyanthum [Wigh.] Walp) bagian tanaman ini (Syzygium Polyanthum [Wight.] Walp) yang sering digunakan yakni daunnya untuk pengobatan beberapa penyakit misal diare, kolesterol tinggi, kencing manis, tekanan darah tinggi, sakit maag. Kandungan kimia yang terkandung dalam daun salam (Syzygium polyanthum [Wight. ]Walp) yaitu minyak asiri, tannin dan flavonoid. Salah satu kandungan (Syzygium polyanthum [Wight.] Walp) yaitu tannin diketahui berkhasiat sebagai atstrigens yaitu dapat meringankan diare dengan menciutkkan selaput lendir usus (Tjay dan Kirana Rahardja, 2002:279)

Dalam penelitian (Noviani.htt:// rac.uii.ac.id: 2005) disebutkan bahwa daun salam (Syzygium polyantum [Wight.] Walp) mempunyai khasiat sebagai antidiare karena ada kandungan tannin. Dengan mengunakan infus daun salam (Syzygium polyantum [Wight.] Walp) dengan dosis 5\%,7,5\%,10\% $\mathrm{b} / \mathrm{v}$, infus daun salam pada dosis $10 \%$ memberikan efek antidiare terbesar bila dibandingkan dengan dosis $5 \%$ dan $7,5 \%$ pada mencit yang didiarekan. Penelitiaan tersebut menyebutkan bahwa semakin tinggi kadar infus daun salam maka daya antidiare infus daun salam semakin meningkat Peningkatan dosis diharapkan akan mengetahui hubungan variabel dosis dengan intensitas efek.

Berdasarkan uraian diatas, peneliti tertarik untuk mempelajari beberapa dosis infuse daun salam (Syzygium polyanthum [Wight.] Walp) diantaranya $(15 \%, 20 \%$, $25 \%, 30 \%, 35 \% \mathrm{~b} / \mathrm{v})$. Peningkatan dosis diharapkan akan mengetahui hubungan variabel dosis dengan intensitas efek.

Dalam penelitian ( Noviani.htt:// rac.uii.ac.id: 2005) menyebutkan bahwa infus daun salam (Syzygium polyanthum [Wigh.] Walp) dengan dosis 5\%, 7,5\%,10\% mempunyai khasiat sebagai antidiare. Pada dosis $10 \%$ memberikan efek antidiare terbesar bila dibandingkan dosis $5 \%$ dan $7,5 \%$ pada mencit yang didiarekan. Penelitiaan tersebut menyebutkan bahwa semakin tinggi kadar infus daun salam maka daya antidiare infuse daun salam semakin meningkat. Peningkatan dosis yaitu $15 \%, 20 \%, 25 \%, 30 \%, 35 \%$ b/v diharapkan mengetahui hubungan variabel dosis dengan intensitas efek.

Sehingga dalam penelitian ini akan diketahui intensitas efek antidiare perlakuan infus daun salam (Syzygium polyanthum [Wingh.t] Walp) dosis15\%, 20\%, $25 \%, 30 \%, 35 \% \mathrm{~b} / \mathrm{v}$ terhadap mencit yang didiarekan.

\section{Metode Penelitian \\ Rancangan Penelitiaan}

Metode yang digunakan dalam penelitian ini adalah eksperimen yang bertujuan (experiment research) yang bertujuan mengetahui efek yang ditimbulkan pada obyek penelitian setelah pengobatan atau pemberian infuse daun salam (Syzygium polyanthium [Wight.] Walp) yang diberikan dengan dosis berbeda pada tiap kelompok obyek penelitian.

Proses penelitian ini terdiri dari tiga (3) tahap. Pertama, tahap persiapan atau perencanaan yang meliputi penentuan obyek penelitian, persiapan alat dan bahan. Kedua tahap pelaksanaan terdiri dari pembuatan sampel dan pemberian sampel pada objek penelitian dan pengamatan perubahan efek yang ditimbulkan pada obyek penelitian yang mengalami diare. Ketiga, tahap akhir yaitu melakukan analisis data dan perhitungan hasil masing masing pengamatan .

\section{Definisi Operasional Variabel}

Klasifikasi Variabel pada penelitiaan ini ada 2 macam yaitu variabel bebas dan variabel tergantung. Variabel bebas dalam penelitiaan ini adalah dosis infus daun salam (Syzygium Polyanthum [Wight.] Walp), dan variabel tergantung adalah intensitas efek antidiare pada mencit yang didiarekan. 
Infus daun salam (Syzygium Polyanthum [Wight] Walp) adalah sediaan cair yang diperoleh melalui perebusan dengan air pada suhu kurang dari $90{ }^{\circ} \mathrm{C}$, diendapkan dan diuapkan.

Frekuensi/jumlah feses pada mencit didefinisikan jumlah rata-rata feses yang dikeluarkan oleh mencit setelah pemberian bahan uji yang didiamkan selama 1 jam lalu diinduksikan minyak jarak dan pengamatan selang satu jam selama empat jam.

Intensitas Efek antidiare daun salam adalah besarnya prosentase daya antidiare berdasarkan jumlah feses, konsistensi feses, dan pengurangan waktu diare.

Skor konsistensi feses Pemberian nilai terhadap pengukuran kepadatan feses setelah pemberikan bahan uji terhadap mencit yang didiarekan dengan skor Feses Cair $=1$, Feses Lembek $=2$, Feses Padat $=3$

\section{Pengumpulan Data}

Untuk mengetahui efek antidiare Infus daun salam diperlukan proses pengumpulan data, adapun prosedur kerjanya sebagai berikut:

3.5.1 Penentuan Obyek Penelitiaan

Penentuan obyek penelitiaan didasarkan pada persyaratan berikut:

- Mencit berjenis kelamin jantan

- Berbobot badan 20-25 gram

- Berusia 40-60 hari

Penentuan Dosis:

1. Dosis I Infus Daun Salam dosis $15 \%$ $15 \mathrm{~g}$ bahan (daun salam) /100 ml air

2. Dosis II Infus Daun Salam dosis $20 \%$ $20 \mathrm{~g}$ bahan (daun salam) $/ 100 \mathrm{ml}$ air .

3. Dosis III Infus Daun Salam dosis $25 \%$ $25 \mathrm{~g}$ bahan (daun salam) $/ 100 \mathrm{ml}$ air

4. Dosis IV Infus Daun Salam dosis $30 \%$ $30 \mathrm{~g}$ bahan (daun salam) $/ 100 \mathrm{ml}$ air

5. Dosis V Infus Daun Salam dosis $35 \%$ $35 \mathrm{~g}$ bahan (daun salam) / $100 \mathrm{ml}$ air

\section{Keterangan :}

Masing- masing dosis tersebut diinfundasikan dengan cara perebusan dengan $100 \mathrm{ml}$ air mendidih dan diuapkan serta diserkai lalu infus tersebut dipipet I ml selanjutnya diberikan pada mencit sesuia kelompoknya

Konversi yang digunakan untuk Loperamid adalah:

Untuk manusia digunakan $2 \mathrm{mg}$ sedangkan untuk mencit adalah $0,0026 \times 2$ $\mathrm{mg}=0,0052 \mathrm{mg}$ (untuk $1 \mathrm{ml}$ pemberian) sedangkan yang dibutuhkan untuk menguji adalah $3 \mathrm{ml}$ maka penimbangan loperamid adalah $0,0052 \times 3=0,0156 \mathrm{mg}$ dalam $3 \mathrm{ml}$ untuk pembuatan $10 \mathrm{ml}$ bahan dilebihkan menjadi $0,0052 \times 10=0,052 \mathrm{mg}$ Bahan 0,052 mg dalam $10 \mathrm{ml}$ air

\section{Prosedur Penelitiaan}

Prosedur penelitiaan dilakukan melalui tahap- tahap sebagai berikut:

1. Mencit dipuasakan makan $1 x 18$ jam minum tetap diberikan sebelum dilakukan percobaan

2. Menyiapkan Infus daun salam dengan berbagi dosis

3. Menyiapkan Minyak jarak dan larutan loperamid

Pengujian antidiare

Mencit dikelompokan menjadi 8 kelompok, masing masing kelompok terdiri dari 3 ekor.
a. Kelompok I : tidak didiarekan
b. Kelompok II : Kontrol (-)
c. Kelompok III : Kontrol (+)
d. Kelompok IV : Infus daun salam dosis $15 \%$
e. Kelompok V : Infus daun salam dosis $20 \%$
f. Kelompok VI : Infus daun salam dosis $25 \%$
g. Kelompok VII : Infus daun salam dosis $30 \%$
h. Kelompok VIII : Infus daun salam dosis $35 \%$

1. Satu jam setelah pemberian bahan uji sebanyak $1 \mathrm{ml}$, mencit diberi minyak jarak $0,75 \mathrm{ml} /$ ekor secara oral diamati selang satu jam selama empat jam.

4 Parameter yang diamati efek yang ditimbulkan pada mencit, frekuensi/jumlah feses, lama terjadinya diare diamati selang satu jam selama empat jam.

5. Memberikan skor setiap konsistensi feses 6. Menganalisa data yang sudah diperoleh.

\section{Analisa Data}

Data yang diperoleh selanjutnya dianalisis menggunakan Analisis Varian (ANAVA) dengan sidik ragam dalam Rancangan Acak Lengkp (RAL), untuk mengetahui efek yang terjadi infus daun salam dosis $15 \%, 20 \%, 25 \%, 30 \%, 35 \%$. terhadap diare pada mencit (Mus Musculus) Adapun Rancangan Penelitian 
sebagai berikut :

Tabel 1. Rancangan Penelitian

\begin{tabular}{|l|l|l|l|l|l|l|l|l|}
\hline \multirow{2}{*}{ Replikasi } & \multicolumn{7}{|c|}{ Perlakuaan } & Total \\
\cline { 2 - 9 } & A & B & C & D & E & F & G & \\
\hline 1 & A1 & B1 & C1 & D1 & E1 & F1 & G1 & \\
\hline 2 & A2 & B2 & C2 & D2 & E2 & F2 & G2 & \\
\hline 3 & A3 & B3 & C3 & D3 & E3 & F3 & G3 & \\
\hline Total & TA & TB & TC & TD & TE & TF & TG & E Xij \\
\hline Rata-rata & XA & XB & XC & XD & XE & XF & XG & \\
\hline
\end{tabular}

Keterangan tabel :

$\mathrm{A}=$ Kelompok tidak didiarekan

$\mathrm{B}=$ Kelompok kontrol (-)

$\mathrm{C}=$ Kelompok kontrol $(+)$

$\mathrm{D}=$ Kelompok uji, Infus Daun salam dosis $15 \mathrm{~g} / 20 \mathrm{~g} \mathrm{bb}$

$\mathrm{E}=$ Kelompok uji, Infus Daun salam dosis 20g/ 20 gbb

$\mathrm{F}=$ Kelompok uji, Infus Daun salam dosis $25 \mathrm{~g} / 20 \mathrm{~g} \mathrm{bb}$

$\mathrm{G}=$ Kelompok uji, Infus Daun salam dosis $30 \mathrm{~g} / 20 \mathrm{~g}$ bb

$\mathrm{H}=$ Kelompok uji, Infus daun salam dosis $35 \mathrm{~g} / 20 \mathrm{~g} \mathrm{bb}$

Rumuskan Hipotesa

- Ho $=\mathrm{mA}=\ldots \ldots \ldots \ldots . . .=\mathrm{mE}$ (Tidak ada perbedaan efek diare pada mencit pada masing-masing kelompok bahan uji)

- HA = mA ?..............? mE (Paling sedikit ada satu kelompok perlakuan yang memberikan perbedaan efek pada mencit .

- Tentukan jumlah pengamatan dari sampel

- Tentukan level signifikan

Jika F hitung berbeda secara nyata, maka dilanjutkan dengan uji student Newman keuls (SNK), untuk mngetahui perlakuan mana yang berbeda secara nyata. Rumus student Newman keuls (SNK) sebagai berikut :

$\mathrm{W}=\mathrm{q}$ a $(\mathrm{P}, \mathrm{fe}) \mathrm{sx}$

$\mathrm{Sx}=\mathrm{v}$ KTG

Pengujian Hipotesa

Jika $H o$ ditolak maka diperlukan pengujian selanjutnya dengan menggunakan uji Student Newman Keul $\left(\mathrm{SNK}_{0,05}\right)$

\section{Hasil Penelitian}

Berdasarkan penelitian yang telah dilakukan terhadap mencit yang didiarekan diperoleh hasil sebagai berikut.
Hasil Penelitian Studi Beberapa Dosis Infus Daun salam sebagai Antidiare dengan dosis yang berbeda, ditandai oleh perubahan jumlah feses, konsistensi feses, serta lama diare yang terjadi pada mencit.

\section{Pembahasan}

Penelitian ini menggunakan daun salam ( Syzigium pholianthum [Wight ] Walp) karena beberapa literatur menyebutkan bahwa tanaman ini mempunyai banyak khasiat untuk menyembuhkan berbagai penyakit salah satunya sebagi obat diare. Secara empiris, daun salam dapat digunakan sebagai obat dalam bentuk tunggal maupun campuran. Metode ekstraksi yang digunakan dalam penelitian ini adalah metode infundasi karena mempunyai keuntungan yaitu proses pengerjaanya sederhana sehingga memudahkan masyarakat untuk membuatnya..

Semua kelompok mencit yang akan digunakan dalam penelitian ini harus dalam keadaan sehat dan tidak stress hal ini dimaksudkan, apabila mencit dalam kondisi stress akan menghambat proses penelitian dan respon yang terjadi pada hewan uji tidak maksimal.Sebelum penelitian dilakaukan, hewan uji harus dipuasakan terlebih dahulu selama 18 - 24 jam hal ini dimaksudkan untuk menjamin bahwa lambung hewan uji benar- benar dalam keadaan kosong pada saat diinduksikan bahan uji secara oral, karena apabila lambung dalam keadaan terisi dapat mengakibatkan bahan uji yang diinduksikan tidak maksimal. Efek purgative yang ditimbulkan dari minyak jarak bukan disebabkan oleh minyak jaraknya melainkan dari kandungan utama minyak jarak yaitu trigliserida dari asam samak risinoleat mengalami hidrolisis dalam usus halus oleh enzim lipase pancreas menjadi gliserol dan asam risinoleat. Zat ini bekerja mengurangi absorbsi cairan dan elektrolit serta menstimulasi peristaltic usus sehingga berkhasiat sebagai laksansia, namun mekanisme kerjanya secara tepat tidak diketahui meskipun terdapat perubahan morfologi dari epitel dinding usus dan perubahan transport dari air dan elektrolit. ( Tjay dan Raharja, $2002: 285$ ).

Bahan obat yang mempunyai khasiat antidiare akan mencegah hewan uji terhadap diare buatan yang diinduksikan Oleum Ricini. Selanjutnya hewan coba mencit yang sudah diinduksikan bahan uji diletakkan 
Tabel 2. Prosentase daya antidiare

\begin{tabular}{|c|c|c|c|}
\hline \multirow[t]{2}{*}{ Perlakuan } & \multirow[t]{2}{*}{$\mathrm{No}_{0}$} & \multicolumn{2}{|c|}{ Daya antidiare berdasarkan } \\
\hline & & Jumlah Feses & Konsistensi Feses \\
\hline \multirow[t]{3}{*}{ B. Kontrol (-) } & I & $20 \%$ & $20 \%$ \\
\hline & II & $24 \%$ & $20 \%$ \\
\hline & III & $0 \%$ & $0 \%$ \\
\hline Rata-rata & & $14,66 \%$ & $13,33 \%$ \\
\hline \multirow{3}{*}{ C.Kontrol $(+)$} & I & $68 \%$ & $59,58 \%$ \\
\hline & II & $64 \%$ & $53,2 \%$ \\
\hline & III & $60 \%$ & $57,45 \%$ \\
\hline Rata-rata & & $64 \%$ & $56,74 \%$ \\
\hline \multirow{3}{*}{ D.Dosis $15 \%$} & I & $44 \%$ & $46,81 \%$ \\
\hline & II & $48 \%$ & $40,43 \%$ \\
\hline & III & $48 \%$ & $42,56 \%$ \\
\hline Rat-rata & & $46,66 \%$ & $43,26 \%$ \\
\hline \multirow{3}{*}{ E. Dosis $20 \%$} & I & $40 \%$ & $31,94 \%$ \\
\hline & II & $60 \%$ & $53,2 \%$ \\
\hline & III & $28 \%$ & $23,41 \%$ \\
\hline Rata - rata & & $42,66 \%$ & $36,18 \%$ \\
\hline \multirow{3}{*}{ F.Dosis $25 \%$} & I & $60 \%$ & $51,07 \%$ \\
\hline & II & $44 \%$ & $55,32 \%$ \\
\hline & III & $64 \%$ & $48,94 \%$ \\
\hline Rata-rata & & $56 \%$ & $51,77 \%$ \\
\hline \multirow{3}{*}{ G.Dosis $30 \%$} & I & $44 \%$ & $29,79 \%$ \\
\hline & II & $12 \%$ & $4,25 \%$ \\
\hline & III & $40 \%$ & $74,46 \%$ \\
\hline Rata- rata & & $32 \%$ & $33,33 \%$ \\
\hline \multirow{3}{*}{ H. Dosis $35 \%$} & $\mathrm{I}$ & $40 \%$ & $38,3 \%$ \\
\hline & II & $44 \%$ & $42,56 \%$ \\
\hline & III & $52 \%$ & $42,56 \%$ \\
\hline Rata-rata & & $45,33 \%$ & $41,14 \%$ \\
\hline
\end{tabular}


dalam kandang secara individu dengan beralaskan kertas putih yang bertujuan untuk memudahkan menghitung jumlah diare yang dikeluarkan mencit dengan cara memberi tanda bercak feses. Dalam penelitan ini sebagai kontrol pembanding digunakan loperamid $\mathrm{HCl} 2 \mathrm{mg}$ / tablet. Loperamid $\mathrm{HCl}$ merupakan obat diare golongan antimotilitas yang dapat menghambat peristaltic dengan cara menekan konstraksi usus. dan pada dosis $25 \%$ mempunyai konsistensi feses lebih besar dari dosis yang lainnya berarti pada dosis $25 \%$ dapat meningkatkan konsistensi feses..

Lama diare yang ditimbulkan dapat dikatakan bahwa dosis $25 \%$ berbeda tidak nyata (memiliki perbedaan yang signifikan ) dengan kontrol positif berarti dosis $25 \%$ memiliki waktu lama diare yang sama dengan kontrol positif.

Tabel 3. Intensitas efek Untuk Dosis

\begin{tabular}{|c|c|c|c|}
\hline \multirow{2}{*}{ Dosis } & \multicolumn{3}{|c|}{ Skor } \\
\cline { 2 - 4 } & $\begin{array}{c}\text { Rata-rata } \\
\text { Jumlah feses }\end{array}$ & $\begin{array}{c}\text { Rata-rata } \\
\text { Konsistensi Feses }\end{array}$ & $\begin{array}{c}\text { Pengurangan Waktu } \\
\text { Diare }\end{array}$ \\
\hline D) Dosis $15 \%$ & $46,66 \%$ & $43,26 \%$ & 40 \\
\hline E) Dosis 20\% & $42,66 \%$ & $36,18 \%$ & 34,99 \\
\hline F) Dosis 25\% & $56 \%$ & $51,77 \%$ & 50 \\
\hline G) Dosis 30\% & $32 \%$ & $33,33 \%$ & 33,33 \\
\hline H) Dosis 35\% & $45,33 \%$ & $41,14 \%$ & 34,99 \\
\hline
\end{tabular}

Dari hasil analisis statistik (ANAVA dan SNK) terlihat bahwa efek antidiare jumlah feses, konsistensi feses, serta lama diare yang dilakukan selama 4 jam. Terlihat bahwa efek antidiare sebagai berikut

Berdasarkan prosentase daya antidiare rata-rata Jumlah feses dapat dikatakan bahwa kontrol negatif berbeda nyata (memiliki perbedaan yang signifikan ) dengan semua dosis maupun kontrol positif , berarti dosis $15 \%, 20 \%, 25 \%, 30 \%, 35 \%$ serta kontrol positif mempunyai efek antidiare.Pada dosis 30\% memiliki efek daya antidiare lebih rendah dari pada dosis $15 \%, 20 \%, 25 \%, 35 \%$ dan kontrol positif . sedangkan dosis $25 \%$ memiliki efek yang sama dengan kontrol positif.

Konsistensi feses kontrol negatif berbeda nyata (memiliki perbedaan yang signifikan ) dengan semua dosis maupun dengan kontrol positif. Berarti kelompok dosis $15 \%, 20 \%, 25 \%, 30 \%, 35 \%$ serta kontrol positif mempunyai efek antidiare.sedangkan dosis $15 \%, 20 \%, 25 \%, 30 \%, 35 \%$, memiliki efek yang sama dengan kontrol positif atau berbeda tidak nyata. Hal ini merupakan bukti bahwa infuse daun salam dosis $15 \%, 20 \%, 25 \%, 30 \%, 35 \%$ mempunyai konsistensi feses sama dengan kontrol positif
Sedangkan dosis 15\%, 20\%, 30\%, $35 \%$ berbeda nyata dengan kontrol positif berati pada dosis tersebut memiliki waktu lama diare yang berbeda. kontrol negative berbeda nyata dengan dosis $15 \%, 20 \%, 25 \%, 30 \%, 35 \%$ berarti pada dosis tersebut memiliki waktu lama diare yang berbeda dengan control negative. Kontrol positif digunakan sebagai pembanding adanya khasiat antidiarenya. Sedangkan kontrol negatif digunakan sebagai pembanding tidak adanya khasiat antidiare.

Dari hasil data tersebut dapat dikatakan bahwa semakin tinggi dosis dari infuse daun salam belum tentu daya antidiarenya semakin besar, Dosis $25 \%$ memiliki daya antidiare tertinggi bila dibandingkan dosis $15 \%, 20 \%, 30 \%, 35 \%$.

\section{Kesimpulan}

Berdasarkan hasil penelitian, daun salam dapat mengurangi jumlah feses, lama diare serta meningkatkan konsistensi feses terhadap mencit. Selain itu, semakin tinggi dosis infuse daun salam yang digunakan untuk antidiare belum tentu daya antidiare infuse daun salam semakin meningkat hal itu terbukti bahwa dosis $25 \%$ memiliki daya 
antidiare tertinggi dibanding dosis $15 \%, 20 \%, 30 \%$, dan $35 \%$.

\section{Daftar Pustaka}

Halliwel, B. dan Gutteridge, J. M. C. 1998. Free Radical and Antioxidant in Human Disease in Analysis of Free Radicals. In Biological System. Berlin

Iwahasi, H. 1998. Mollecular Mechanism of Pancreatic Beta Cell Destruction in Autoimmune Disease : Potential Target For Preventive Therapy, Cytokines, Cellular and Mollecular Therapy 94: 45-51

Jakus, V. 2000. The Role of Free Radical, Oxidative Stress and Antioxidant System in Diabetic Vascularr Disease. Bratisl. Lek. Listy. 101:541551

Jansson, T., Wennergren, M. dan Illsley, N. P. 1993. Glucose Transporter Protein Expression In Human Placenta Throughout Gestation And In Intrauterine Growth Retardation. Journal of Clinical Endocrinology \& Metabolism, Vol 77, 1554-1562

Jones, V. 1996. Methods in Molecular Medicine, Human Cell Culture Protocols. King's College University of London. Humana Press. UK

Junquiera, C. L., Carneiro, J. dan Kelley, O. R (Tambayong, J). 1998. Edisi ke8. Penerbit Buku Kedokteran EGC. Jakarta 